\title{
The Use of Cartoon Media for Junior High Students of Their Writing Ability
}

\author{
Siswandi \\ State Islamic University of Sultan Syarif Kasim Riau, Indonesia \\ siswandi@uin-suska.ac.id
}

\begin{abstract}
This research was proposed from the problem of students writing ability in the descriptive text of the eight-grade students at MTs N 1 Pekanbaru. They were not able to write in English well. The objective of this research was to find out whether there was or nor the significant effect of using cartoon media. The design of this research was Quasi-Experimental Research. The Population of this research was all of the eighthgrade students. The total number of the population was 350 students. The writer used a cluster sampling technique by taking only two classes as a sample; VIII.1 that consisted of 35 students as experimental class and VIII. 2 consisted of 35 students as control class. So the number of samples from two classes was 70 students. To analyze the data, the writer used an independent sample t-test. Based on the analysis of the t-test Formula, the sig. value is 0.000 . It could be stated that $0.000<0.05$. Then, the effect size is 0.387 categorized into a moderate level. The writer concluded that there is a significant effect of using cartoon media on students' writing ability in the descriptive text at MTs N 1 Pekanbaru. And the biggest effect occurred on the writing ability where the effect size is 0.14 categorized into large effect.
\end{abstract}

\section{Keyword: Cartoon Media, Teaching Writing Ability, Descriptive Paragraph.}

\section{A. Introduction}

Writing is an activity that students need time to do it. For this, students need time to get ideas to express in their writing. However, many students complain that they do not know what to write. They can neither link sentences into coherent paragraphs, nor express this thought clearly. Writing skill is complex and sometimes difficult to learn, requiring mastery not only of the grammatical and rhetorical device but also of conceptual and judgmental elements (Heaton 1988: 135).

Therefore, the teacher has to make creative methods to teach writing subjects by using a media of teaching writing. Learning through media can be one of the solutions to motivate students' interest in learning English. The media can be used in learning English are movie, television, books, radio, etc. It means that there is no limitation in learning English. (Etemadi, 2012).

Media such a cartoon can stimulate the students to express their ideas in writing. Based on Hamid (in Purwoto, p.3) aids will stimulate the students and make material taught to be more interesting and impressive. The picture is painting, drawing, draft, 


\section{Siswandi-The Use of Cartoon Media For Junior High Students of Their Writing Ability}

sketch, and cartoon. Especially as a work of art. Cartoon will make students interested in studying; it will make students focus on the lesson given. The cartoon can describe the real condition interestingly. Cartoons can attract students' attention and develop students' motivation. Students can study effectively if the teachers use visual media like cartoons in the learningteaching process.

Based on a preliminary researcher at MTs N 1 Pekanbaru by asking the English teacher, the researcher found some problem such as, some of the students had difficulties in using grammatical orders in writing a descriptive paragraph, They could not write a descriptive paragraph clearly, They also got the problem to write based on generic structure of the descriptive paragraph and students to have difficulties in selecting appropriate vocabularies in writing a text.

To solve the problem above, the researcher uses Cartoon Media to improve the students writing ability in case of a Descriptive Paragraph. Media such a cartoon can stimulate the students to express their ideas in writing. Based on Hamid (in Purwoto, p.3) aids will stimulate the students and make material taught to be more interesting and impressive.

The cartoon is media that can be used by the teacher in the learning and teaching process. Media is a learning source for students. It can stimulate students' motivation in the learning process. Cartoon will make students fell interested in studying; it will make students focus this statement is supported by Ali (in Musnil, 2006,p.89) that teaching media can stimulate the students' need, though, attention, talent, and motivate students to study. So that students will be easier to write English well.
Furthermore, Farhant (1981, in Hamid, p.4) says that teaching media is categorized into three kinds, they are: first, teaching basis media such as whiteboard, textbook, and worked book. Second, Nonelectric media such as picture, card, graphic, statute, painting, and poster. And the last, electronic teaching media such as video, movie, projector, and television. Characteristics of cartoons are using caricature, criticism, and humorist. The cartoon is painting or caricaturing about people, situation, idea which is designed to influence the society opinion (Nana, 1991, p.58 )

Based on the formulation of the problems above, this research is necessary to be carried out to achieve the objectives of the research as follows: first, to find out whether there is or not any significant effect of using cartoon media on students' writing ability at MTs N 1 Pekanbaru. Then, to find out on which component of writing ability does the use of cartoon media have the biggest effect on students' writing ability in the descriptive paragraph.

\section{B. Theoretical Framework}

Writing ability is the skill to express ideas, though, and feeling to others people in written symbols to make other people or reader understand the ideas conveyed, it means that writing ability is an ability of the person to express his or her ideas, feeling, or something in his or her minds to others by using written language.

Another definition is given by Broughton, Geofrrey, et, al. (1980:116) that when we write, unlike when we talk, we are engaged in an activity which is usually at the same time both private and public. It is private because the act of composition is by its nature 
solitary, but it is public in that most writing is intended for an audience, often one which is extremely difficult to define.

Medwell, wray, et, al. (2009:114) also states that Writing often seems a very mysterious process. When we write, somehow or other ideas which are in our heads, perhaps only in the very vaguest of forms, have to be shaped into coherent representations in language and transferred onto paper, screen, or other media so they can be inspected by some other person.

Harmer in How to Teach

English stated that in writing, students need to know some of the writing's special convention (punctuation, paragraph construction, etc.) just as they need to know how to pronounce spoken English appropriately (2001:80). Meanwhile, according to Nunan (2003:89), each candidate will be required to write short English composition, correct in spelling, punctuation, grammar, and expression in which the subject to be taken from such work of standard authors will be announced from time to time. It means writing is not a simple work, in writing the writer should consider the use of spelling, punctuation, grammar, and expression.

Furthermore, According to Barker's (2009, in Afrilyasanti and Basthomi, 2011:557), state that the best way to keep our students interested and engaged in lessons is by making them interactive. These activity pages give information on how to enable students to analyze cartoons while using currently relevant materials as a guideline for lessons. The design of teaching using the cartoon to develop 21-century learners can be described into pre-teaching, whilst-teaching, and post-teaching:
The pre-teaching activity engaged was addressed to prepare the students with the topic taught. Some questions were asked to the students to investigate their background Knowledge on the topic that would be discussed and set the students to focus on it.

Asking the students to give opinions on their interest in cartoons and comics, such as How many of you like reading, watching, or drawing cartoons? Who's your favorite cartoon or comic character? Why do you like them? asking students' background of knowledge on the topic that will be discussed, such as: Have you ever heard the word "racism"? What does it mean? Have you ever found racism, intolerance, or discrimination in your surrounding? What is it?

Some activities applied in the whilst-teaching were purposed to dig up students' understanding of the implicit meaning within the cartoon. Besides, the activities also aimed at stimulating students' awareness of the situations happening in their society. Furthermore, they could be at the level of having critical and analytical thinking. Finally, the students were targeted to be able to produce their cartoon and comic strips relating to the topic. The post-activity was employed to look into the students' product.

Based on an explanation before, the researcher concluded that teaching writing descriptive paragraphs taught by using cartoon media on students writing ability in descriptive paragraphs at MTs N 1 Pekanbaru was better than taught without using Cartoon Media. Thus, there was a significant effect of using Cartoon Media to improve students' writing ability in a descriptive paragraph of the eighth grade at MTs N 1 Pekanbaru. 


\section{Siswandi - The Use of Cartoon Media For Junior High Students of Their Writing Ability}

\section{Research Design}

This research was experimental. According Gay et.al., (2012), experimental research is the only type of research that can test hypotheses to establish a causeeffect relationship. In this research, the writer proposed to test whether there was an effect of using cartoon media on students' writing ability. The writer used a quasi-experimental design, the design of pre-test and post-test which used two groups as the sample. The research was conducted in February 2020 at MTs N 1 Pekanbaru.

The number of the population is 350 students. Considering the population of this research is large, the researcher used Cluster random sampling to take the sample. The samples of this research are the students of VIII.1 as experimental class and VIII.2 as control class which both consisted of 70 students.

This research used a quasiexperimental design. In conducting the research, the writer conducted try out to test the validity and reliability of test items. The test that was used in collecting the data of the research was multiple-choice questions that consisted of twenty items and a short-answer question consisted of five items. The questions were made based on indicators that were stated in the syllabus used by MTs N 1 Pekanbaru.
After testing validity and reliability, the writer conducted a pretest and posttest in both the experimental and control class. The treatment was given in the experimental class. After completing the research, the data was analyzed through the Independent Sample T-test formula by using SPSS 25 Version.

The data was collected using the test. The test was used to find out the students' writing ability. The test was multiple-choice questions that consisted of 20 items and a shortanswer question consisted of 5 items. The data of this research were the score of the students' writing ability obtained by using the test.

The data was analyzed by using independent samples t-test formula calculated by using SPSS and continued by calculating effect size using eta square formula.

\section{Research Finding}

Before examining the effect of using cartoon media on students' writing ability of descriptive text at MTs N 1 Pekanbaru, the writer calculated the mean, standard deviation, and standard error mean of experimental and control class by using SPSS, can be seen in the following table: 

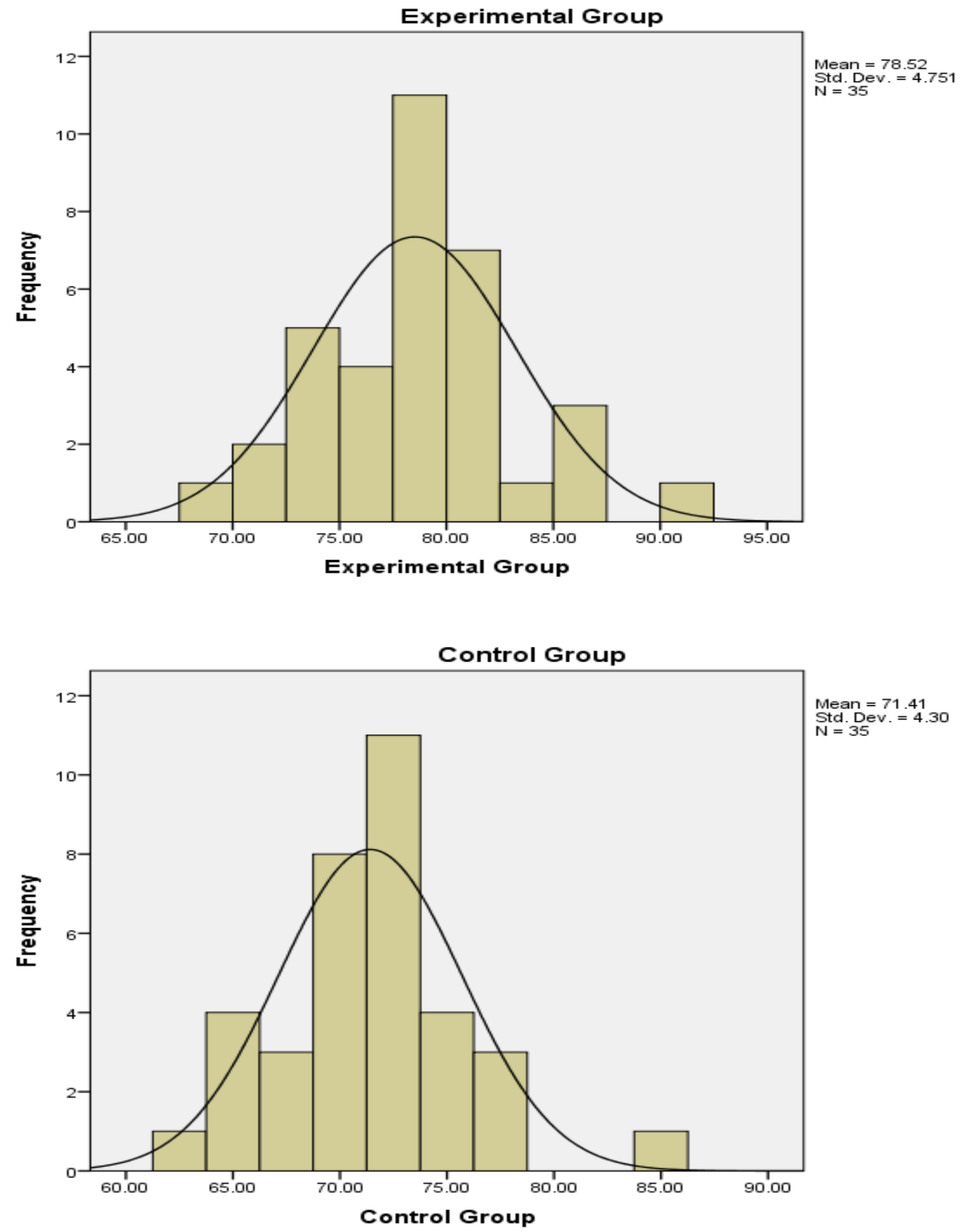


\section{Siswandi - The Use of Cartoon Media For Junior High Students of Their Writing Ability}

\section{Descriptive Statistics}

\begin{tabular}{llrr}
\hline & & Experimental Group & Control Group \\
\hline \hline $\mathrm{N}$ & Valid & 35 & 35 \\
& Missing & 0 & 0 \\
Mean & & 78.5163 & 71.4143 \\
Median & 78.4300 & 71.5000 \\
Mode & $68.63^{\mathrm{a}}$ & 71.50 \\
Std. & 4.75086 & 4.30028 \\
Deviation & 22.571 & 18.492 \\
Variance & 23.82 & 21.50 \\
Range & 68.63 & 62.50 \\
Minimum & 92.45 & 84.00 \\
Maximum & 2748.07 & 2499.50 \\
Sum & &
\end{tabular}

Based on the table above, the total number of students for the experimental class consisted of 35 students and the control class consisted of 35 students. The mean score of the experimental class was 78.5163 and the mean score of the control class was 71.4143, and the standard deviation of the experimental class was 4.75086, while the standard deviation of the control class was 4.30028 .

To examine the effect of using cartoon media on students' writing ability, the writer analyzed the data by using the independent sample ttest formula calculated by using SPSS. The result showed that sig. value is 0.000 . It can be stated that $0.000<0.05$. It means there is a statistical difference between the experimental and control class.
Then, to identify the level of the effect of using cartoon media on students' writing ability of descriptive text at MTs N 1 Pekanbaru, it was calculated by using eta squared formula. The result showed that the effect size is 0.387 categorized into moderate effect. It means that the use of cartoon media has a moderate effect on students' writing of the descriptive text.

Based on research finding which has already discussed above, it can be concluded that the use of cartoon media has an important role in improving students' vocabulary knowledge which also can improve their writing ability. Finally, this research is expected can give valuable reference for the next researchers who are interested in researching a similar discussion topic. 


\section{REFERENCES}

Afrilyasanti, Basthomi. 2011. Language in India Strength for Today and Bright Hope for Tomorrow. Vol 11. ISSN 1930-2940.

Amrizal. 2015. Cartoon As Instructional Method in Teaching Descriptive Text writing. Ahmad Dahlan Journal of English Studies(ADJES). Vol.2.

Broughton, Geofrrey, et, al. 1980. Teaching English as A Foreign Language Second Edition. London and New York: Rouledge.

Creswell, John W. 2008. Educational Research: Planning Conducting and Evaluating Quantitative and Qualitative Research. New Jersey: Pearson Education Ltd.

Etemadi, A. 2012. Effects of Bimodal Subtitling of English Movies on Content Comprehension and Vocabulary Recognition, 2(1), 239248. doi:10.5539/ijel.v2n1p239

Genese, Fred, and A Upshur,Jhon. 1996.Classroom-Based Evaluation in Second

Language
Education. Cambridge: Cambridge University Press

Harmer, Jeremy. 2001. How to Teach English. Malaysia: Pearson Education Longman.

Heaton, JB. 1998. Writing English Language Test. New York: Edinburg Gate.

Nana Sudjana, and ahmad Rifai. 1991. Media Pengajaran. Bandung: CV Sinar Baru

Nunan, David. 2003. Practical English Language Teaching. New York: McGraw-Hills Companies, Inc.

Medwell, Jane, et, all. 2009. Primary English Teaching Theory and Practices Fourth Edition. Shothernhay East: Learning Matters Ltd.

Purwoto. 2007. "teaching writing by using the picture on the second-year student of MTs LKMD Kasikan", Pekanbaru: Unpublished. 